\title{
Growth and effect of mycoplasmas in Fallopian tube organ cultures
}

\author{
D. TAYLOR-ROBINSON AND F. E. CARNEY JR.* \\ Division of Communicable Diseases, M.R.C. Clinical Research Centre, Watford Road, Harrow, \\ Middlesex $H A 13 U \mathcal{F}$
}

Mycoplasmas cause respiratory disease in many mammalian and avian species. In human subjects it is indisputable that Mycoplasma pneumoniae causes upper and lower respiratory tract disease. On the other hand, the evidence put forward by some that mycoplasmas found in the urogenital tract are responsible for disease in this area is open to criticism. This is especially true for non-specific urethritis in men (Hare, Dunlop, and Taylor-Robinson, 1969).

In women, it seems that strains of $M$. hominis may occasionally cause post-partum fever (Harwick, Purcell, Iuppa, and Fekety, 1971) and Mårdh and Weström (1970a, b) believe that some strains may cause acute salpingitis. Organ cultures of Fallopian tissue in which ciliary motility may be used as a guide to cell viability and integrity have been used before to study infections with viruses (Barski, Cornefert, and Wallace, 1959; Casal, Rubenstein, Votava, and Tyrrell, 1970) and Neisseria gonorrhoeae (Carney and Taylor-Robinson, 1973). We have inoculated such cultures with mycoplasmas of the human urogenital tract, as mentioned briefly before (Taylor-Robinson, 1971). We hoped that this might provide information on the behaviour and pathogenicity of these organisms, in the same way as other organ cultures have proved useful in studying the pathogenicity of mycoplasmas isolated from the respiratory tract (Taylor-Robinson, 1973).

\section{Material and methods}

\section{MYCOPLASMAS}

A genital strain of Mycoplasma hominis, $M$. orale type 1, and various genital and oral $\mathrm{T}$-mycoplasmas of human origin were used. In addition, $M$. hyorhinis of porcine origin and $\mathrm{T}$-mycoplasmas of simian and bovine origin were studied.

Received for publication September 21, 1973

*Visiting worker from Department of Obstetrics and Gynecology, Shands Teaching Hospital, Gainsville, Florida 32601, U.S.A.
MEDIA

Mycoplasmas

Liquid medium for growth of arginine-metabolizing mycoplasmas consisted of PPLO broth (Difco) containing 20 per cent. $(\mathrm{v} / \mathrm{v})$ unheated horse serum, 10 per cent. ( $v / v)$ of a 25 per cent. ( $w / v)$ extract of dried yeast, 0.05 per cent. thallium acetate, 1000 units penicillin $\mathrm{G} / \mathrm{ml}$., $0 \cdot 1$ per cent. arginine, and 0.002 per cent. phenol red (Manchee and Taylor-Robinson, 1968). M. hyorhinis was grown in the same medium but with the arginine replaced by 0.1 per cent. glucose, while for $\mathrm{T}$-mycoplasmas, the arginine was replaced by $0 \cdot 1$ per cent. urea and 0.025 per cent. thallium was used. Thallium was omitted from mycoplasma media to be inoculated into organ cultures. Media containing arginine or urea were adjusted to $\mathrm{pH} 7 \cdot 8$. Medium was solidified by the addition of 1.0 per cent. Noble agar.

Organ culture

Fallopian tube organ cultures were maintained usually in Eagle's minimal essential medium containing penicillin 100 units $/ \mathrm{ml}$. and $0.05 \mathrm{M}$. HEPES buffer, the $\mathrm{pH}$ being adjusted to $7 \cdot 2$ with $\mathrm{NaOH}$ or $\mathrm{NaHCO}_{3}$. In one experiment the cultures were maintained in a mixture of equal parts of Eagle's medium and mycoplasma medium in which the horse serum was replaced by 20 per cent. human serum.

\section{FALLOPIAN TUBE ORGAN CULTURES}

Preparation

Total or partial salpingectomy specimens were collected directly from the operating theatre and all subsequent procedures were done in a 'Microflow' laminar flow cabinet as described before (Carney and Taylor-Robinson, 1973). Briefly, the specimens were cut into pieces 0.3$0.5 \mathrm{~cm}$. square with a scalpel and placed singly or in pairs in $5 \mathrm{~cm}$. plastic Petri dishes on grid marks which had been scored with a scalpel. Medium ( $3 \mathrm{ml}$.) was added to each dish and these were then placed in air-tight plastic boxes which were flushed with a 5 per cent. $\mathrm{CO}_{2}$-air mixture and incubated at $37^{\circ} \mathrm{C}$.

\section{Ciliary activity}

This was observed at the fringes of tissue pieces by means of an inverted microscope (100 $\times$ magnification) and 
transmitted light, or over the whole mucosal surface using conventional microscopy (40 $\times$ magnification) and oblique illumination to highlight the cilia. Accurate quantitation of ciliary activity was not possible and normally cultures were assessed for the presence or absence of activity.

\section{Histology}

Specimens were fixed in formol-saline or in Bouin's solution, processed by routine histological methods and stained with haematoxylin and eosin.

\section{TITRATION OF MYCOPLASMAS}

Medium removed from organ cultures was diluted in 10fold steps in $1.8 \mathrm{ml}$. amounts of liquid mycoplasma medium contained in tightly-capped vials of $2 \mathrm{ml}$. capacity. These were incubated at $37^{\circ} \mathrm{C}$. until colour changes ceased to occur. The end-point of the titration was the highest dilution causing a colour change and was considered to contain one colour-changing unit (CCU). Some specimens were titrated also on solid medium and mycoplasma colonies were counted after incubation at $37^{\circ} \mathrm{C}$. in an atmosphere of 5 per cent. $\mathrm{CO}_{2}$ in nitrogen. The number of organisms was expressed as colonyforming units (CFU).

\section{IDENTIFICATION OF MYCOPLASMAS}

Large colony-forming mycoplasmas were identified by means of specific rabbit antisera either in the disc growthinhibition test (Clyde, 1964) or in the metabolisminhibition test (Taylor-Robinson, Purcell, Wong, and Chanock, 1966).

\section{Results}

\section{DURATION OF ORGAN CULTURE PRESERVATION}

Ciliary activity was used as an index of organ culture viability. Activity persisted in most cultures for a period of 14 days and in some for 1 month and occasionally longer. Penicillin in the concentrations used did not seem to have a detrimental effect on the viability of the cultures.

\section{GROWTH OF MYCOPLASMAS IN ORGAN CULTURES}

\section{Mycoplasmas of human origin}

The results of several experiments in which organ cultures were inoculated with mycoplasmas of human origin are summarized in Table $I$ and in the Figure. $M$. hominis organisms were recovered usually in low numbers and they persisted often until the experiments were terminated. The number of $M$. hominis organisms was not seen to increase in the culture fluids. However, since the fluids were changed, we estimate that multiplication of organisms probably or undoubtedly occurred in eight of ten experiments. In one experiment, not shown in Table I, in which the culture medium was supplemented with mycoplasma medium, the titre of viable organisms reached $10^{7} \mathrm{CCU} / \mathrm{ml}$. after 3 days. $M$. orale type 1 behaved similarly to $M$. hominis. Likewise, genital and oral T-mycoplasma strains multiplied and sometimes persisted in the cultures (Table I, overleaf).

\section{Mycoplasmas of non-human origin}

The results of experiments with mycoplasmas of non-human origin are summarized in Table II (overleaf).

Growth of $M$. hyorhinis and of T-mycoplasmas of simian origin occurred; T-mycoplasmas of bovine origin probably multiplied.

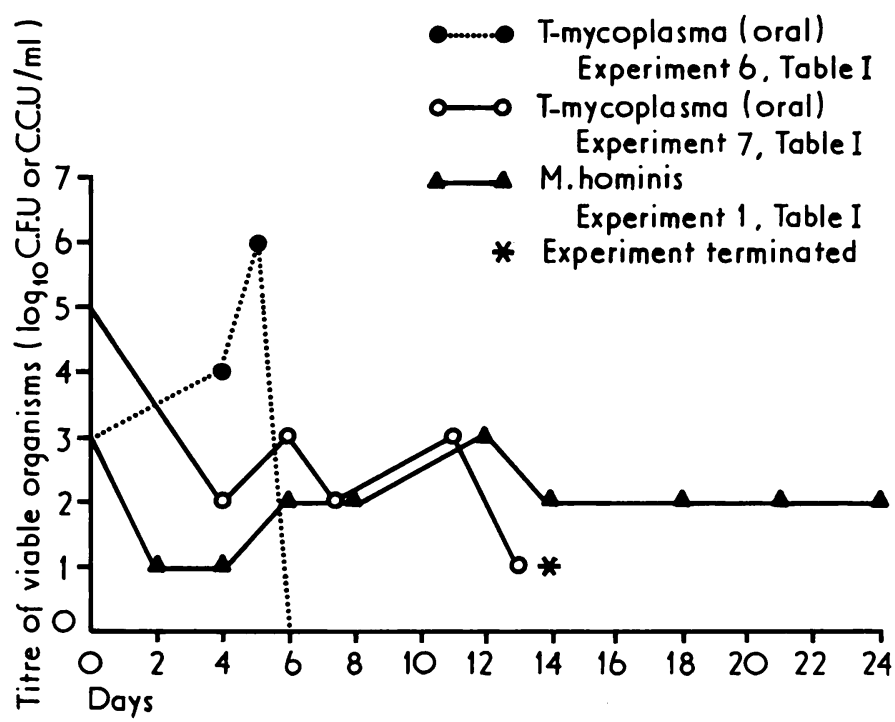

FIGURE Recovery of mycoplasmas from experimentally infected organ cultures of three Fallopian tubes 
TABLE I Growth of mycoplasmas of human origin in Fallopian tube organ cultures

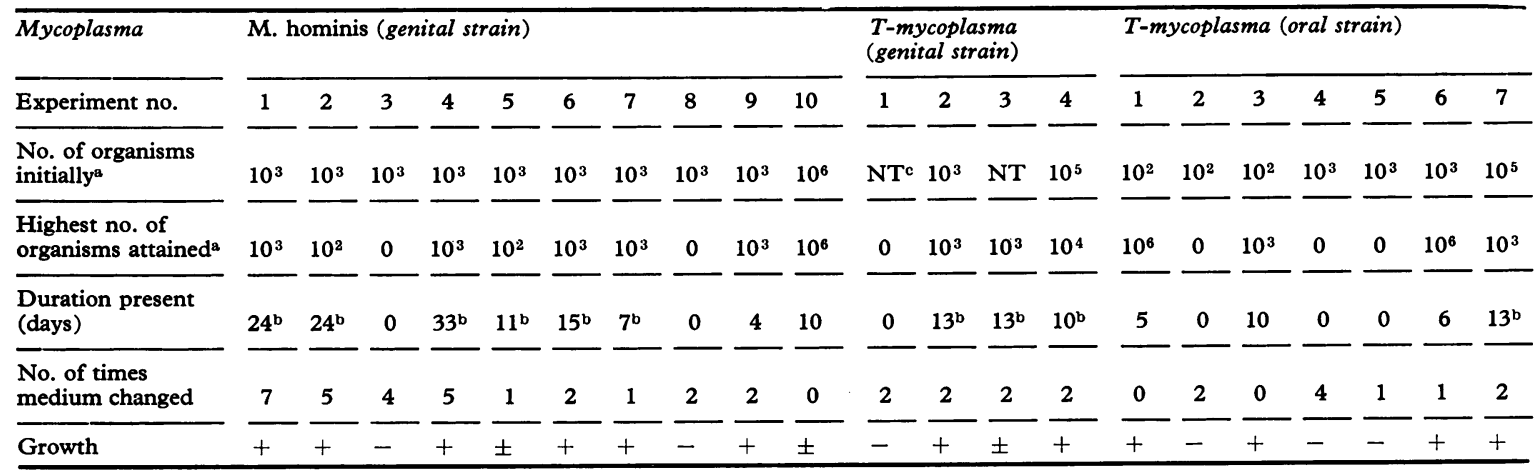

${ }^{\mathrm{a}} \mathrm{M}$. hominis in $\mathrm{CFU} / \mathrm{ml}$; $\mathrm{T}$-mycoplasmas in $\mathrm{CCU} / \mathrm{ml}$.

bExperiment terminated at this time

\pm Indicates probable growth + indicates undoubted growth

cNT $=$ not tested

TABLE II Growth of mycoplasmas of non-human origin in Fallopian tube organ cultures

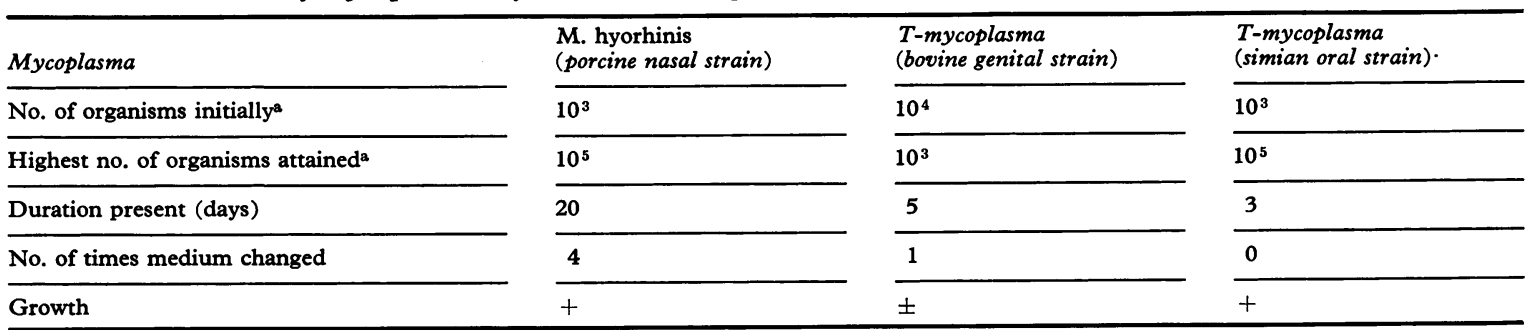

${ }^{\mathrm{a}} \mathrm{M}$. hyorhinis in CFU/ml.; T-mycoplasmas in CCU $/ \mathrm{ml}$.

\pm Indicates probable growth + indicates undoubted growth

\section{GROWTH OF MYCOPLASMAS IN CONDITIONED MEDIUM}

Organisms $\left(10^{6} \mathrm{CFU} / \mathrm{ml}\right.$.) of $M$. hominis died within $48 \mathrm{hrs}$ when incubated at $37^{\circ} \mathrm{C}$. in organ culture medium without tissue. Medium samples, removed from uninfected cultures after 3 and 5 days' contact with the Fallopian tissue (conditioned medium), were inoculated with $10^{4} \mathrm{CFU} / \mathrm{ml}$. of $M$. hominis and incubated at $37^{\circ} \mathrm{C}$. Viable mycoplasma organisms continued to exist for 8 and 6 days, respectively, although an increase in numbers was not detected. Other mycoplasmas were not tested.

\section{CILIARY ACTIVITY OF ORGAN CULTURES}

The rate of loss of ciliary activity in cultures inoculated with either large colony-forming or T-mycoplasmas was no different from the loss in uninoculated cultures, even in the cultures in which the medium was supplemented with mycoplasma medium.

\section{HISTOPATHOLOGY OF ORGAN CULTURES}

In comparison with uninoculated cultures, no pathological changes were observed in cultures inoculated with $M$. hominis. Histopathological examination of other mycoplasma-infected organ cultures was not done.

\section{Discussion}

Many mycoplasmas have fastidious growth requirements in vitro, but the mycoplasmas that we have tested are able to multiply in the Fallopian tube organ culture system. Growth of mycoplasmas was not dependent on the presence of active cilia. However, their growth required the presence of tissue. This has been noted with $M$. capri in chicken tracheal organ cultures (Cherry and TaylorRobinson, 1970), and Reed (1972) observed that complete organ cultures always supported growth of mycoplasmas better than conditioned medium 
harvested from the same cultures. Proof of mycoplasma growth in the Fallopian tube organ cultures was sometimes difficult to establish in instances where the number of organisms recovered from the culture fluids did not exceed the number inoculated. Since mycoplasmas are often tissue associated, it is possible that we might have recovered larger numbers of organisms by homogenizing the tissues. Nevertheless, the fact that organisms could be recovered sometimes several weeks after inoculation of cultures in which their numbers had been reduced by one or more medium changes strongly suggested that multiplication had occurred. Persistence of the organisms was a feature of cultures inoculated with mycoplasmas, and in this regard the infections were similar to the chronic contamination of tissue cultures with some mycoplasmas (Stanbridge, 1971) and the chronic infection of the genito-urinary tract observed in humans (Holmes, Furr, and TaylorRobinson, 1974).

Although mycoplasmas of a particular animal species may sometimes infect another, it seems that for the most part they are confined to one species. However, in tissue cultures and to a lesser extent in organ cultures (Taylor-Robinson, 1973), this is not so. The results of the experiments reported here, in which mycoplasmas derived from various animal species grew in the Fallopian organ cultures, amply confirm this contention. Even though chronic infections were established, in no instance was damage, as judged either by loss of ciliary activity or by histopathological changes, observed in mycoplasma-infected cultures. This was so even when the organ culture medium was supplemented with mycoplasma medium which stimulated $M$. hominis organisms to multiply so that they were present in large numbers. Of course, failure to demonstrate that mycoplasmas cause damage in organ cultures does not necessarily indicate that they do not have pathogenic potential for man. Lemcke and Csonka (1962), on the basis of a serological study, first suggested that $M$. hominis had a role in acute salpingitis. Mårdh and Weström $(1970 \mathrm{a}, \mathrm{b})$ demonstrated antibody responses to $M$. hominis in some patients with the disease and isolated the organisms directly from the tubes. However, chlamydial agents have not so far been sought in this site, so that the idea that $M$. hominis is a primary pathogen is still not beyond dispute.

We have also studied Neisseria gonorrhoeae in Fallopian tube organ cultures (Carney and TaylorRobinson, 1973) and it is of interest to compare the effects of this bacterium with those of mycoplasmas (Table III). N. gonorrhoeae organisms always multiplied in the cultures whereas mycoplasmas did not always do so and gonococci were not tissuedependent. Furthermore, N. gonorrhoeae, a known pathogen, rapidly damaged the Fallopian tube organ cultures whereas mycoplasmas of questionable pathogenicity did not.

TABLE II Comparison of mycoplasmas and N. gonorrhoeae in Fallopian tube organ cultures

\begin{tabular}{llll}
\hline Feature studied & \multicolumn{2}{c}{ Presence or absence of feature with } \\
\cline { 3 - 3 } & Mycoplasmas & N. gonorrhoeae \\
\hline Growth in organ culture & + & + \\
Growth in 'conditioned' medium & - & + \\
Persistence in organ culture & + & - \\
Loss of ciliary activity & - & + \\
Histopathological changes & - & + \\
\hline
\end{tabular}

\section{Summary}

Ciliary activity persisted in most Fallopian tube organ cultures for 14 days and in some for one month and occasionally longer. Mycoplasma hominis multiplied and persisted in most cultures and this was also a feature of T-mycoplasmas of both genital and oral origin. Species specificity was not apparent because mycoplasmas of non-human origin also grew in the cultures. Growth of $M$. hominis was tissue-dependent, since the organism did not multiply in conditioned medium, that is medium which has been removed from cultures after several days of contact with the tissue. In no instance was damage, as judged either by loss of ciliary activity or by histopathological changes, observed in mycoplasma-infected cultures.

\section{References}

BARSKI, G., Cornefert, F., and Wallace, R. E. (1959) Proc. Soc. exp. Biol. (N.Y.), 100, 407

Carney, F. E., Jr., and TayloR-Robinson, D. (1973) Brit. F. vener. Dis., 49, 435

Casal, J., Rubenstein, D., Votava, M., and Tyrrell, D. A. J. (1970) Arch. Virusforsch., 31, 196

Cherry, J. D., and TAYlor-Robinson, D. (1970) Infect. and Immun., 2, 431

Clyde, W. A., Jr. (1964) f. Immunol., 92, 958

Hare, M. J., Dunlop, E. M. C., and Taylor-Robinson, D. (1969) Brit. F. vener. Dis., 45, 282

Harwick, H. J., Purcell, R. H., Iuppa, J. B., and FeKeTY, F. R., Jr. (1971) Obstet. and Gynec., 37, 765

Holmes, M., FurR, P., and TAYLOR-Robinson, D. (1974) f. Hyg. (Camb.), In press

LemCKe, R. M., and Csonka, G. W. (1962) Brit. f. vener. Dis., 38, 212

MancheE, R. J., and TaYloR-Robinson, D. (1968) f. gen. Microbiol., 50, 465

MÁRDH, P.-A., and WESTRÖM, L. (1970a) Brit. f. vener. Dis., 46, 179

— (1970b) Ibid., 46, 390 
Reed, S. E. (1972) f. comp. Path., 82, 267

StanBRIDGE, E. (1971) Bact. Rev., 35, 206

Taylor-Robinson, D. (1971) Proc. roy. Soc. Med., 64, 31 (1973) In 'Airborne Transmission and Airborne Infection', ed. J. F. P. Hers and K. C. Winkler, p. 196. Oosthoek, Utrecht

, Purcell, R. H., Wong, D. C., and Chanock, R. M. (1966).f. Hyg. (Camb.), 64, 91

Croissance et action des mycoplasmes sur les cultures de tissu de trompes de Fallope

\section{SOMMAIRE}

L'activité ciliaire a persisté dans la plupart des cultures de tissu de trompes pendant 14 jours, dans quelques cas pendant un mois et, occasionnellement, plus longtemps. Mycoplasma hominis se mutliplièrent et persistèrent dans la plupart des cultures et ceci fut aussi une caractéristique des mycoplasmes de souche $T$, qu'ils soient d'origine génitale ou orale. La spécificité d'espèce ne fut pas apparente car des mycoplasmes d'origine non humaine poussèrent aussi dans les cultures. La croissance de $M$. hominis s'est montrée 'tissu-dépendante' dans le sens que l'organisme ne se multiplia pas dans un milieu conditionné, c'est-à-dire dans un milieu qui a été déplacé des cultures après plusieurs jours de contact avec le tissu. En aucun cas il ne fut observé de dommage, que l'on en juge par la perte de l'activité ciliaire ou par des modifications histo-pathologiques, dans les cultures où le mycoplasme avait poussé. 